\title{
Venoarterial carbon dioxide gradient utility as a criterion for blood transfusion at the intensive care unit
}

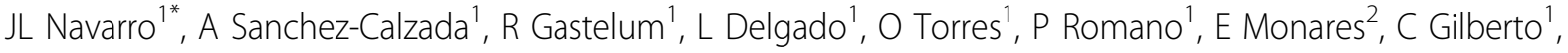 \\ J Franco ${ }^{1}$
}

From ESICM LIVES 2015

Berlin, Germany. 3-7 October 2015

Intr

Currently there is controversy about criteria for blood transfusion in critically ill patients by a level of hemoglobin and specially as a strategy to raise the venous oxygen saturation (Sv02).

\section{Objectives}

To analyze de utility of the venoarterial carbon dioxide gradient (V-a PC02) to detect those patients who will respond with a rise of Sv02 to blood transfusion.

\section{Methods}

Patients within their first 12 hours from admission to the intensive care unit (ICU) during the hemodynamic optimization protocol in which blood transfusion was decided to rise the Sv02 after hemodynamic optimization: central venous pressure $(\mathrm{CVP})>8 \mathrm{mmHg}$, mean arterial pressure (MAP) $>65 \mathrm{mmHg}$, peripheral oxygen saturation $(\mathrm{Sp} 02)$ $>90 \%$. Pre and post transfusion hemoglobin, venous oxygen saturation (Sv02), and V-a PC02 were measured, then divided in two groups: "Responders" (R) if a rise $>5 \%$. In Sv02 after transfusion was present and in "Non responders" (NR) with a rise $<5 \%$ in Sv02 after transfusion. Receiver Operating Characteristic (ROC) curve analysis was performed to asses the utility of the pre transfusion $\mathrm{V}-\mathrm{a} \mathrm{PC} 02$ as a tool to predict responsiveness of the Sv02 to blood transfusion.

\section{Results}

73 patients were analyzed, mean age of $68 \pm 2$, with 35 (47.9\%) males, $25(34,25 \%)$ patients in the R group and $48(65,75 \%)$ in the NR group.

${ }^{1} \mathrm{ABC}$ Medical Center, Intensive Care, Mexico, Mexico

Full list of author information is available at the end of the article
ROC curve analysis were performed resulting in an area under the curve of $0.82(\mathrm{p}<0.01$; CI 0.73-0.91) with a pre transfusion V-a PC02 cutoff value of $\geq 6$ showing a sensibility $66 \%$ of and a specificity of $84 \%$ for predicting those patients who will not respond with a rise greater than $5 \%$ in the post transfusion Sv02.

\section{Conclusions}

$\mathrm{V}$-a PC02 $>6 \mathrm{mmHg}$ identifies those patients that will no show a rise of the $\mathrm{Sv} 02$ as a response to blood transfusion.

Authors' details

${ }^{1}$ ABC Medical Center, Intensive Care, Mexico, Mexico. ${ }^{2}$ Hospital San Angel Inn Universidad, Intensive Care, Mexico, Mexico.

Published: 1 October 2015

doi:10.1186/2197-425X-3-S1-A221

Cite this article as: Navarro et al:: Venoarterial carbon dioxide gradient utility as a criterion for blood transfusion at the intensive care unit. Intensive Care Medicine Experimental 2015 3(Suppl 1):A221.

Submit your manuscript to a SpringerOpen ${ }^{\bullet}$ journal and benefit from:

- Convenient online submission

- Rigorous peer review

- Immediate publication on acceptance

- Open access: articles freely available online

- High visibility within the field

Retaining the copyright to your article

Submit your next manuscript at $>$ springeropen.com

\section{SpringerOpen ${ }^{\circ}$}

C 2015 Navarro et al.; This is an Open Access article distributed under the terms of the Creative Commons Attribution License (http:// creativecommons.org/licenses/by/4.0), which permits unrestricted use, distribution, and reproduction in any medium, provided the original work is properly cited. 